\title{
Developing a Collection on Africa, South of the Sahara
}

By ADELAIDE C. HILL

T

'HE GROWING significance of modern Africa can be easily assessed by the frequent appearance of scholarly as well as popular books on some aspect of African life. While a goodly number of American universities and colleges have a concentration of courses dealing with Africa, no university library would be complete without acquiring some material in this field.

College librarians perform the crucial role of making available the necessary written data to insure the development of competent scholarship in a given field. To achieve scholarship in the field of African affairs, whether we like it or not, one must work with considerable speed and urgency. The librarian, therefore, should have some frame of reference for necessary guidance in developing a useful collection. Considering the size of Africa as a continent, the infinite diversity of its people, the complexity of its problems, and the all too real difficulty of securing books and reports, the suggestions made here do not presume to be final or complete in scope. It is merely claimed that they are noteworthy contributions toward the development of scholarship in this field.

Perhaps the easiest to secure but the costliest to own are the so-called traditional or classical books on Africa. These books, historical in treatment, form the background or core of any good African collection: Stanley's Travels, Du Chaillu's tales, Bruce's Travels, Baker's Explorations, and so forth, to mention only a few. It is an open secret, I guess, that much of the interest in Africa could have
Dr. Hill is Research Associate, African Studies Program, Boston University.

been reinforced a few years ago at bargain prices in Europe. Now, all the overseas booksellers, as well as those in this country, are aware of the growing interest on the part of American libraries in African material and the amount of money that is being allocated to acquisitions in the African field; therefore, the prices asked for these materials reflect this knowledge.

The average American college librarian may have fallen prey to the myth that "little is known" about Africa and may be overwhelmed at making a selection from what appears to be an extremely wide and diversified field. A good gauge, however, of the growth of interest in recent years in Africa may be noted in the Books on Africa Catalogue, recently published by the University Place Bookshop in New York City. This one catalog, which lists books printed from the early nineteenth century to date, has more than 200 of the 785 which have been published since 1950. Another measure of the magnitude of this growing interest in Africa and acquisitions in the African field may be gleaned from the fact that almost 5,000 books were listed in the African collection of the Moorland Foundation of Howard University, which was published in 1958 , indicating that these holdings were up-to-date to, say, 1957.

The character of published material on Africa has mirrored rather interestingly 
the changes in our image of the continent and in the seriousness of our purpose towards it. But, beginning with a minimum requirement for a solid library, a librarian, plagued with the problem of a limited budget, may seek with confidence one of the so-called "classic treatments" of the subject. There would be little controversy over the fact that $A n$ African Survey, published by Lord Hailey, the eminent English scholar and administrator, in 1936 and revised in 1956, would be considered as a basic "classic" treatment of African material. Here, in its 1,615 pages of text, the African continent is studied through the compilations of a number of distinguished Africanists from many fields on the basis of its people, its languages, its political and social objectives, its systems of government, its administration, and so forth. This is indeed the encyclopedic treatment.

The earliest and perhaps in some ways the most extraordinary endeavor towards total coverage of Africa and its problems are the two volumes by Raymond Buell, The Native Problem in Africa. As the labor of primarily one man, this work is amazingly complete. It is significant to note that Buell, writing in his preface in 1927, said: "Africa is the one continent of the world where the white man still has carte blanche to avoid the mistakes of the past committed in other parts of the world, if he has the will and intelligence to do so."

A final recommendation for an over-all discussion of Africa is the recently published two-volume work Tropical Africa by George Kimble, formerly the director of the American Geographical Society and now chairman of the Department of Geography at the University of Indiana. Kimble, sponsored by the Twentieth Century Fund, devoted more than five years to this research and was able, as was Lord Hailey, to marshall the assistance of many scholars in the field.

When one moves from total conti- nental coverage to special subjects or special areas, one of the earliest of the modern books on Africa which comes to grips with the dilemma of the day is Negley Farson's Behind God's Back, published in 1941. This is an intellectual travelogue of observations on Southwest Africa, South Africa, Tanganyika, Kenya, Uganda, Ruanda-Urundi, Congo, French West Africa, and the French Cameroons. It represents the last pre-war report of the "raw material and people, behind God's back waiting for the brave new world." This is a pre-Mau Mau, prenationalistic Africa treatment.

Many Americans are likely to forget how important World War II was to Africa and to the latent aspirations of African leaders as well as to acceptance on the part of the colonial powers of the inevitable future of the continent: Britain before France, France before Belgium, Belgium before Portugal, and perhaps Portugal before the Afrikander, but all see a new Africa. And this appreciation, albeit begrudgingly in many instances, of change in Africa has stimulated a tremendous outpouring of literature during the last fifteen years. Many categories of material appealing to an interested, but not necessarily academic or scholarly, public are represented.

There is, for example, the simplified general treatment type of book which is roughly in the tradition of Hailey and Buell. An example would be Africa: $A$ Study in Tropical Development by $\mathrm{L}$. Dudley Stamp, professor of social geography at the University of London; or Contemporary Africa: A Continent in Transition by $\mathrm{T}$. Walter Wallbank; or C. Groves Haines' collection of articles entitled Africa Today; or, more recently. Cultures and Societies of Africa, edited by Simon and Phoebe Ottenberg. Africa Emergent, written by W. M. MacMillan, first published in 1938 and revised and expanded in 1948, is another useful volume. It is a completely adequate explanation of the key factors with which 
one should be familiar in order to understand the problems of modern Africa. Less well-known but equally stimulating is John Hatch's little book of lectures, originally given in the extra-mural programs of British universities, entitled Africa Today and Tomorrow: An Outline of Basic Facts and Major Problems. The most recent of the short, readable, and adequate attempts at total coverage is Anthony Sampson's Common Sense about Africa. Sampson, an Englishman, after serving four years as the editor of Drum, a magazine published in the Union of South Africa for Africans, succeeds admirably in giving the reader the basic information with which he could view modern Africa with common sense.

For those who seek more specialized knowledge, as is usually the case with a college library, it is hard to decide just what to choose. Should we approach Africa subject-wise, that is, acquire books on politics, on economics or art; or should we concern ourselves primarily with adequate geographical coverage concentrating on South Africa, on Ghana, on Liberia, or on Kenya? And how to separate the useful and non-biased from those of more lasting quality? Authors who approach Africa with understanding appreciate a need for seriousness which is reflected, I think, even in the titles chosen for their works: Algeria in Turmoil, Africa's Challenge to America, Transition in Africa, The Death of Africa.

In recent years, there has been a marked decline in the importance of the travelogue as such. Obviously travel to Africa today is becoming too possible or familiar to justify that type of writing. In addition, through the daily press, television, Ed Murrow, Chet Huntley, magazines such as Time, Life, and so forth, the image of Africa to the American public has changed. To be of value or interest to the intelligent reader, even a travelogue must be focused and informed. Fenner Brockway's African Jour$n e y s$, which gives his observations of con- ditions in East Africa, is an informed travelogue.

For the average alert student there are anthropological books of value in giving meaning to our understanding of the present. The Fon and His Hundred Wives by Rebecca Reyber; Baba of Kano, A Woman of the Moslem Hausa by M. F. Smith; or the recent The Harmless People, on the Bushmen, by Elizabeth Marshall Thomas, are a look at the present through the past. This type of writing pretends to be nothing more than it is, mainly a sympathetic treatment of African life lived in its traditional way. Traditional societies and values are portrayed as significant and functional, that is, humane.

Just now the current literature on Africa seems to concentrate upon the conditions in a particular part of the continent. Perhaps no other part of Africa has more written on it than South Africa, but all the books seem to be "pleas" to the conscience of mankind. South Africa, the Road Ahead, a composite of several different points of view edited by Hildegard Spottiswoode, is a collection of essays on such suggested topics as: a better life for all workers, the dynamics of separate development, through colored glasses, false gods, towards a new deal for those between. Though written before the disturbances of last March, it provides a clear insight into the issues facing that part of Africa. A sympathetic and sensitive plea is Father Huddleston's Naught for Your Comfort; and Alan Paton, known for his many articles on South Africa and the moving story Cry, the Beloved Country, has written a brief statement of action, Hope for South Africa, in which he defines the position of the Liberal and the role of the Liberal Party in South Africa. Paton feels that Liberals must be blunt in their rejection of total Apartheid as an intellectual pipedream. He does urge strong outside support. Gwendolen Carter, Politics of Inequality: South Africa Since 1948, has 
written a fully documented account of the sad state of politics in South Africa. On and on one could go, but it is significant that the control on the black man in the Union is so strong that we rarely, if ever, see writings by him from there.

Until the Mau Mau outbreaks of the early 1950s, East and Central Africa were treated in the literature as happy animal reserves for white hunters and ideal spots of settlement for Europeans; little was written about the usual problems of race relations or African development. Then came the Mau Mau and the prosecution of its leader, Jomo Kenyatta. With that crisis came an outpouring of interpretations, analyses, and justifications. Aside from the three official government documents, the Royal Commission Report, the Psychology of the Mau Mau by Dr. Carothers, and F. D. Corfield's Historical Survey of the Origins and Growth of Mau Mau (Cmd 1030), five other books provide background for understanding of this part of Africa and this emergency: Jomo Kenyatta's autobiography, Facing Mount Kenya; the Trial of Jomo Kenyatta by Montague Slater; Mbiyu Koinange's The People of Kenya Speak for Themselves; L. S. B. Leakey's $D e$ feating Mau Mau, and Mau Mau and the Kikuyu by the same author. As Mau Mau was virtually a war by Africans against Europeans, as with most wars, it will be discussed and re-discussed for many years to come. Much of the material on East Africa will certainly continue to sympathize with one side or the other. It is, therefore, particularly gratifying to see the little book by Ronald E. Wraith, East African Citizen. This is one of the most useful and well-documented source books on this section of Africa from the point of view of the interested, not necessarily scholarly, reader.

Central Africa, or, more specifically, the Federation of Rhodesia and Nyasaland, has had neither the crisis of Mau Mau nor the tragedy of Apartheid, and the current literature on this area reflects the artificiality of the calm which many people seem to feel reigns there, at least, it did so until the Nyasaland riots of a year ago and the Southern Rhodesia riots of last July.

Africa in Transition, edited by Prudence Smith, is a series of talks given on BBC by outstanding authorities on Central and South Africa. It covers everything from health to the status of living, cases for the special ethnic groups, and features of the social structure. The lack of urgency in its presentation describes the attitude of most persons at that time. Even the well-documented book Independent African by George Shepherdson tells the story of John Chilembwe and the Nyasa rising of 1915 , which certainly relates to many factors of modern nationalism, but is safely stated in the context of the past.

Almost the opposite point of view or reaction is felt when one reads Dawn in Nyasaland by Guy Clutton-Brock or Black Government by Kenneth Kaunda and Colin Morris, or A New Deal in Central Africa by Colin Leys and Cranford Pratt. Viewed in the context of modern Africa, there has been little of significance, other than political writings, on East and Central Africa. This is not, of course, to ignore the important ethnological studies that appear with a good deal of frequency on this part of Africa, an example of which would be East African Chiefs edited by Audrey Richards. This is a series of studies covering fourteen tribes of British East Africa and includes 1,154 case histories of chiefs and sub-chiefs. It represents the first instance of the collecting of life histories of tribal authorities, and because of this all the data in it would appear significant.

However, to get the greatest amount of variety in the literature on Africa, one must turn to West Africa. Here African writers have been most vocal as novelists, poets, protest writers, and scholars. Un- 
doubtedly, the circumstances of development there have been a tremendous stimulant to writing. In addition, there are five universities in West Africa, not to mention several important secondary schools, all of which would encourage Africans to write and others to read what they have written. It is hard to make a choice when considering West Africa; it is a bit easier to make a list. Turning first to the novels which are always valuable sources for insight about a new part of the world, not to mention the familiar parts, one selects Wreath for Udomo by Peter Abrams, a South African writer, as certainly a significant treatment of the wanderings and activities of an emerging nationalist who leaves his country, goes to England, and returns. Interestingly enough, Abrams, who has now found his way to the West Indies, is a South African, but he chose to write this moving book on that part of Africa which does have in it so many features of interest and attraction. There is also Dark Child, the sensitive treatment of growing up in French West Africa by Camara Laye; this was later reissued as African Child.

One of the most promising of the West African novelists, Amos Tutuola, is a Nigerian whose limited education (only six years of schooling) is credited for his ability to write as an African, unspoiled and uninfluenced by European style. His two works are Palm Wine Drinker and The Brave African Huntress.

There are two well-received compilations of literature: Peggy Rutherford edited African Voices, an anthology of native African writings published by Vanguard this past year; and the Anthology of West African Verse compiled by Olumbe Bassii and published by the Ibadan University Press, 1957.

It is important for all libraries to have in their collections significant books by Africans other than novels or poetry. It is true that some of the more critical works or certainly the most significant
African authors wrote years ago and many of their books are not now available, but I would want to suggest the names of Edward Blyden of Sierra Leone and J. E. Casely-Hayford of Ghana as men of learning and writers of stature. Casely-Hayford's Gold Coast Native Institutions and Ethiopia Unbound are suggested. Blyden's classic book is Christianity, Islam, and the Negro Race. Unfortunately, these books may be somewhat difficult to get; nevertheless, they are worthy additions to an African collection. Three other books should not be overlooked in order to provide knowledge about contemporary political leaders. One is An Autobiography of Kwame Nkrumah, which was published in 1957. The second is Path to Nigerian Freedom by Obafemi Awolowo. Awolowo has long had a reputation of being a sophisticated and brilliant Yoruba politician in $\mathrm{Ni}$ geria, and with the coming of Nigerian independence, his influence and his role will be noteworthy. The third book is the recently published autobiography of Awolowo entitled: Awo: The Autobiography of Chief Obafemi Awolowo.

No library, either college or general, would be complete without having one or more of the works of George Padmore. Padmore was not of African but of West Indian birth, but aside from being a prolific writer, his importance to Africa is the role he played in developing the idea of Pan-Africanism. George Padmore came to Ghana to live and work as a close confidential advisor to President Nkrumah. He died in his fifties in England, where he went for a brief holiday. His remains are now in Christianburg Castle in Ghana as one of the great fighters for the freedom of Africa. George Padmore's three books are of vital importance: Africa: Britain's Third Empire; The Gold Coast Revolution; and Pan-Africanism, the Coming Struggle for Africa.

Drawing from among the many books which have come out on West Africa in 
recent years, I do not wish to neglect two books very well known in American academic circles: Gold Coast in Transition by David Apter and Nigeria: Background to Nationalism by James Coleman. In addition to these scholarly works which are fundamental and basic, there are certain other special books which are concerned with particular subjects relative to West Africa. A History of Education in British West Africa by Colin G. Wise is a useful document which stresses primarily the growth of education in that part of Africa where westernized education has been of longest duration and greatest influence. Another useful book for background reading, based particularly on the West African scene, is the West African Councillor by I. D. Cameron and B. K. Cooper. This small book affords an understanding of the development of local government, elections, and the possibility for future development in the field of local government in West Africa.

For many years the possibility of historical research in Africa has been much debated. But the initiation a year or two ago of The Journal of African History and some recently published books suggest the growth of a new and interesting field of writing. For the historical-minded who wish to chart a course between "the rock of prejudice and the whirlpool of romance," Basil Davidson's The Lost Cities of Africa is a fascinating and wellwritten account. Though the Davidson book is concerned with the historical roots of all of Africa, it is not surprising that this new interest in history finds roots in West Africa. J. D. Fage, then a professor at the University College of Ghana, published An Introduction to the History of West Africa, which is simple, short, and adequate. Faculty from the University College of Ghana started Journal of African History and for years the Sierra Leone Historical Society has published its journal, Sierra Leone Studies, full of facts of West African history.
Last year also Kenneth Dike, Nigerian historian and archivist and presently the principal of the University College of Nigeria at Ibadan, edited a series of studies originally broadcast by the $\mathrm{Ni}$ gerian Broadcasting Corporation and published as Eminent Nigerians of the 19 th Century. Its usefulness lies in the fact that it calls attention to the existence of persons in the past who fought and resisted the invasion of Africa, or certainly Nigeria, by the colonial powers.

The anthropologist, the historian, the traveller, the sociologist, and the missionary have long been writing on Africa, but because of the new image of Africa, colleagues from other disciplines are now concerned with African subject matter. John Phillip's Agriculture and Ecology in Africa, subtitled $A$ Study of Actual and Potential Development South of the Sahara, is a scholarly and technical study for the specialist in agriculture. Mark Karp's Economics of Trusteeship in Somalia presents a balanced factual analysis of the economy of one of the newest of the African states, though the pastoral economy of Somalia, as he sees it, is hampered by inadequate water, poor roads, and virtually no rail transportation or markets of easy access. This type of situation, though in the extreme in Somalia, is not unknown in other parts of Africa, and an analysis of one economy at this level of development certainly has relevance to consideration of economic planning for other sections of Africa. A final book in this style of specialized pioneering work on Africa is African Homicide and Suicide edited by Paul Bohannan and attempts to determine whether Africans kill themselves and one another for the same reasons and in the same situations as Europeans and Americans. This work in comparative criminology is based on a study of seven tribes of British Africa. It is a cooperative endeavor with other scholars using comparable outlines for their tribes (Continued on page 479) 


\title{
Developing a Collection on Africa
}

\author{
(Continued from page 443)
}

which they knew best in order to get comparative data.

Many persons, including students, still think first of art and Africa; and it could certainly be that the art department of a university stimulates the interest in Africa. Among the several recently published books on African art are African Folktales and Sculpture (Bolligen Series XXXII), The Sculpture of Africa by Eliot Elison, William Fagg, and Bernard Quint, and Africa, The Art of Negro People by Elsy Leuzinger.

There is almost no limit within the scope of a paper of this nature to the number of books on Africa one might recommend. Each week brings another possibility. And beyond the rich field of books on Africa lie the equally important ones of journals and government reports, for government documentation and the scholarly or timely article are the surest sources of material on modern Africa. All countries publish their legislative proceedings, and some publish departmental reports which can be secured, as a rule, from the government printer of the country. There is a wealth of material appearing in journals on Africa published either in the countries of Africa or in some cases still in the metropole. A proper guide to source and entry could be an article in itself. Suffice it to say here, however, that they exist and are valuable for certain types of collec. tions. Even the daily press, in reporting on this or that political event, may call attention to a recent government report of critical significance, as, for example, The East African Royal Commission Report, The Devlin Report, The Tomlinson Report, and The Monckton Report.

One cannot conclude a survey of representative literature on Africa without bringing to the attention of the college librarian the publications of some of the more important research institutes in Africa. These institutes are located all over the continent, many have regional offices, and they publish both journals and monographs. The more important of these institutes concerned with social and economic problems are L'Institut d'Afrique Noire (I.F.A.N.) at Dakar, L'Institut d'Etudes Centrafricaines (I.E.C.) at Brazzaville, The West African Institute of Social and Economic Research (W.A.I.S.E.R.) at Ibadan, The South African Institute of Race Relations at Johannesburg, The East African Institute of Social Research at Kampala, The Rhodes-Livingstone Institute at Lusaka, La Centre d'Etudes des Problems Sociaux Indigenes (C.E.P.S.I.) at Elizabethville, and L'Institut pour la Recherche Scientifique en Afrique Centrale (I.R.S.A.C.) at Livino-Katana. This list does not include the important institutes outside Africa, such as The International African Institute in London, which publish regularly and significantly on African affairs.

Perhaps as a postscript for college librarians in America, one may be able to assume the knowledge, particularly at this time, of two important statements on Africa made by Americans. One is Chester Bowles' little book, Africa's Challenge to America. In this book, written four years ago, Bowles, prophetically enough, calls attention to the fact that the United Nations is the forum through which America must work in giving its support to African countries. He does not equivocate as to his feelings about the responsibility of America to play a decisive role in Africa, irrespective of the historical ties it has with Europe. The timeliness of Bowles' observations and the personal opportunity he has to 
be of influence at this time should certainly warrant consideration of this book.

At this writing, perhaps the most outstanding document relating to United States government policy and Africa is the report Africa, A Study-Prepared at the Request of the Committee on Foreign Relations of the United States Senate by the Program of African Studies at Northwestern, under the chairmanship of Professor Melville Herskovits. Long a scholar in the field of African affairs, Herskovits has fifteen recommendations tor the United States foreign policy towards Africa. He makes it perfectly clear that we have had no policy toward Africa in the past and that this country should initiate a strong and aggressive policy which would be in the best interests of all concerned.

There is little doubt that future government reports and books developing and criticizing the ideas of Bowles and Herskovits will be forthcoming.

\section{Bibliography}

1. Stanley, Henry M., In Darkest Africa; or The Quest, Rescue and Retreat of Emin, Governor of Equatoria, in 2 vols. (New York: Charles Scribner's Sons, 1891).

2. Du Chaillu, Paul, The Country of the Dwarfs (New York: Harper and Brothers, 1872).

- Stories of the Gorilla Country (New York: Harper and Brothers). - A Journey to Ashango-land (New York: Harper and Brothers, 1874). - Explorations in Equatorial Africa.

3. Bruce, James, Travels To Discover the Source of the Nile; in the Years 1768, $1769,1770,1771,1772$ and 1773 , in 8 vols. (Edinburgh, 1804).

4. Baker, Samuel White, The Albert N'yanga, Great Basin of the Nile, in 2 vols. (London: Macmillan and Co., 1866).

5. Porter, Dorothy B. (ed.), A Catalogue of the African Collection in the Moorland Foundation, Howard University Library (Washington: The Howard University Press, 1958).

6. Hailey, Lord, An African Survey, Revised 1956 (London: Oxford University Press, 1957).

7. Buell, Raymond Leslie, The Native Problem in Africa, Vols. I and II (New York: The Macmillan Co., 1928).

8. Kimble, George, H. T., Tropical Africa; Vol. I, Land and Livelihood; Vol. II,
Society and Polity (New York: The Twentieth Century Fund, 1960).

9. Farson, Negley, Behind God's Back (New York: Harcourt, Brace and Co., 1941).

10. Stamp, L. Dudley, Africa, A Study in Tropical Development (New York: John Wiley and Sons, 1953).

11. Wallbank, T. Walter, Contemporary Africa, Continent in Transition (New Jersey: Anvil by Van Nostrand, 1955). (Paperbound).

12. Haines, C. Grove (ed.), Africa Today (Baltimore: Johns Hopkins University Press, 1955).

13. Ottenberg, Simon and Phoebe (eds.), Cultures and Societies of Africa (New York: Random House, 1960).

14. MacMillan, W. M., Africa Emergent: $A$ Survey of Social, Political, and Economic Trends in British Africa (Revised and Expanded) (Penguin Books, Harmondsworth, Middlesex, Pelican Books, 1949).

15. Hatch, John, Africa: Today and Tomorrow, An Outline of Basic Facts and Ma. jor Problems (New York: Frederick A. Praeger, 1960).

16. Sampson, Anthony, Common Sense about Africa (New York: The Macmillan Company, 1960).

17. Clark, Michael K., Algeria in Turmoil, $A$ History of the Rebellion (New York: Frederick A. Praeger, 1959).

18. Bowles, Chester, Africa's Challenge to 
America (California: University of California Press, 1957).

19. Carter, Gwendolen M. and W. O. Brown, (eds.), Transition in Africa: Studies in Political Adaptation (African Research Studies No. 1. Boston: Boston University Press, 1958).

20. Ritner, Peter, The Death of Africa (New York: The Macmillan Co., 1960).

21. Brockway, Fenner, African Journeys (London: Victor Gallancz, Ltd., 1955).

22. Reyber, Rebecca, The Fon and His Hundred Wives (Garden City, New York: Doubleday and Company, Inc., 1952).

23. Smith, Mary, Baba of Kano (New York: The Philosophical Library, 1955).

24. Thomas, Elizabeth Marshall, The Harmless People (London: Secker and Warburg, 1959).

25. Spottiswoode, Hildegarde (ed.), South Africa, the Road Ahead (Cape Town: Howard Timmins, 1960).

26. Huddleston, Trevor, Naught for Your Comfort (London and Glasgow: Collins Clean-Type Press, 1956).

27. Paton, Alan, Cry, The Beloved Country (New York: Charles Scribners' Sons, 1948).

28. - Hope For South Africa (New York: Frederick A. Praeger, 1959).

29. Carter, Gwendolen M., The Politics of Inequality. South Africa Since 1948 (New York: Frederick A. Praeger, 1958).

30. East Africa Royal Commission, Report (1953-55) (London: H.M.S.O., Cmd 9475, 1955).

31. Carothers, J. C., Psychology of the Mau Mau (Nairobi: Government Printer, 1957).

32. Corfield, F. D., Historical Survey of the Origins and Growth of Mau Mau (London: H.M.S.O., Cmd 1030, May, 1960).

33. Kenyatta, Jomo, Facing Mount Kenya, The Tribal Life of the Gikuyu (London: Martin Secker and Warburg, Ltd., 1938).

34. Slater, Montague, The Trial of Jomo Kenyatta, second edition revised (London: Secker and Warburg, 1957).

35. Koinange, Mbiyu, The People of Kenya Speak for Themselves (Detroit: Kenya Publication Fund, 1955).

36. Leakey, L.S.B., Defeating Mau Mau (London: Methuen and Co., Ltd., 1954).

37. —, Mau Mau and the Kikuyu
(London: Methuen and Co., Ltd., 1952).

38. Wraith, Ronald E., East African Citizen (London: Oxford University Press, 1959).

39. Smith, Prudence (ed.), Africa in Transition (London: Max Reinhardt, 1958).

40. Shepherdson, George and Thomas Price, Independent African, John Chilembwe and the Origins, Setting, and Significance of the Nyasaland Native Rising of 1915 (Edinburgh: The University Press, 1958).

41. Clutton-Brock, Guy, Dawn in Nyasaland (The Netherlands: Hodder and Stoughton, 1959).

42. Morris, Colin and Kenneth Kaunda, Black Government, $A$ Discussion Between (Lusaka: United Society For Christian Literature, 1960).

43. Leys, Colin and Cranford Pratt (eds.), $A$ New Deal in Central Africa (London: William Heisemann, Ltd., 1960).

44. Richards, Audrey (ed.), East African Chiefs (London: Faber and Faber, Ltd., 1960).

45. Abrams, Peter, Wreath for Udomo (New York: Alfred A. Knopf, 1956).

46. Laye, Camara, The African Child; Memories of a West African Childhood (London and Glasgow: Collins Clean-Type Press, 1954).

47. Tutuola, Amos, The Palm Wine Drinker (London: Faber and Faber, Ltd.).

48. - The Brave African Huntress (New York: The Grave Press, n.d.).

49. Rutherford, Peggy, African Voices, An Anthology of Native African Writing (New York: Vanguard Press, 1959).

50. Bassii, Olumbe, An Anthology of West African Verse (Ibadan University Press, 1957).

51. Casely-Hayford, Gold Coast Native Institutions (London: Sweet and Maxwell, Ltd., 1903).

52. - Ethiopia Unbound (London: C. M. Phillips, 1911).

53. Blyden, E. W., Christianity, Islam and the Negro Race (London: W. B. Whittingham and Co., 1888).

54. Nkrumah, Kwame, An Autobiography of Kwame Nkrumah, (Edinburgh: Thomas Nelson and Sons, Ltd., 1957).

55. Awolowo, Obafemi, Path to Nigerian Freedom (London: Faber and Faber, Ltd., 1946).

56. — Awo: The Autobiography of 
Obafemi Awolowo (New York: Cambridge University Press, 1960).

57. Padmore, George, Africa, Britain's Third Empire (London: Dennis Dobson, Ltd., 1954).

58. Padmore, George, The Gold Coast Revolution (London: Dennis Dobson, Ltd., [1953]).

59. — Pan-Africanism, The Coming Struggle for Africa (London: Dennis Dobson, Ltd., [1956]).

60. Apter, David E., The Gold Coast in Transition (Princeton: Princeton University Press, 1955).

61. Coleman, James, Nigeria, Background to Nationalism (Berkeley: University of California Press, 1958).

62. Wise, Colin G., A History of Education in British West Africa (London: Longmans, Green and Co., 1956).

63. Cameron, I. David and B. K. Cooper, The West African Councillor (London: Oxford University Press, 1954).

64. Davidson, Basil, The Lost Cities of Africa (Boston: Little, Brown and Co., 1959).

65. Fage, J. D., An Introduction to the History of West Africa (New York: Cambridge University Press, 1957).

66. Nigerian Broadcasting Corporation, Eminent Nigerians of the Nineteenth Century (New York: Cambridge University Press, 1960).

67. Phillips, John, Agriculture and Ecology in Africa (London: Faber and Faber, 1959).

68. Karp, Mark, The Economics of Trustee- ship in Somalia (African Research Studies, Number Two. Boston: Boston University Press, 1960).

69. Bohannan, Paul (ed.), African Homicide and Suicide. (Princeton: Princeton University Press, 1960).

70. Radin, Paul (ed.), African Folktales and Sculpture (Bolligen Series XXXII. New York: Pantheon Books, Inc., 1952).

71. Elison, Eliot, William Fagg, and Bernard Quint, The Sculpture of Africa (London: Thames and Hudson, 1958).

72. Leuzinger, Elsy, Africa, The Art of the Negro People. (Art of the World Series. New York: McGraw-Hill, 1960).

73. Report of the Nyasaland Commission of Inquiry (London: H.M.S.O., Cmd 814, 1959).

74. Summary of the Report of the Commission for the Socio-Economic Development of the Bantu Areas within the Union of South Africa (Pretoria: Government Printer, U.G. 61-1955).

75. Advisory Commission on the Review of the Constitution of Rhodesia and Nyasaland (London: H.M.S.O., Cmd 1149-50, 1960).

76. Herskovits, Melville J. (chairman), Africa, $A$ Study-Prepared at the Request of the Committee on Foreign Relations of the United States Senate, by the Program of African Studies, Northwestern University, Pursuant to S. Res. 366, 85th Congress, and S. Res. 31, 86th Congress, No. 4, October 23, 1959 (Washington: Government Printing Office, 1959).

\section{Catholic Association Scholarship}

The Catholic Library Association announces a scholarship in library science for the academic year 1962-1963, to be awarded for graduate study toward a master's degree. The scholarship consists of an award of $\$ 600.00$ to the person chosen by the Scholarship Committee of the Catholic Library Association. Religious, as well as lay people, are eligible.
The recipient may enter the graduate library school of his choice.

Applications, available from the Scholarship Committee, Catholic Library Association, Villanova, $\mathrm{Pa}$., must be filed at the Catholic Library Association headquarters by January 15,1962 . The award will be announced at the annual conference of the association in April 1962. 